\title{
The T. N. Coles Site (41RR3): An Early Caddo Period Burial Mound Site on the Sulphur River, Red River County, Texas
}

Timothy K. Perttula

Heritage Research Center, Stephen F. Austin State University

Follow this and additional works at: https://scholarworks.sfasu.edu/ita

Part of the American Material Culture Commons, Archaeological Anthropology Commons, Environmental Studies Commons, Other American Studies Commons, Other Arts and Humanities Commons, Other History of Art, Architecture, and Archaeology Commons, and the United States History Commons

Tell us how this article helped you.

This Article is brought to you for free and open access by the Center for Regional Heritage Research at SFA ScholarWorks. It has been accepted for inclusion in Index of Texas Archaeology: Open Access Gray Literature from the Lone Star State by an authorized editor of SFA ScholarWorks. For more information, please contact cdsscholarworks@sfasu.edu. 


\section{The T. N. Coles Site (41RR3): An Early Caddo Period Burial Mound Site on the Sulphur River, Red River County, Texas}

\section{Creative Commons License}

\section{(c) (1) (8)}

This work is licensed under a Creative Commons Attribution-NonCommercial 4.0 International License 


\title{
The T. N. Coles Site (41RR3): An Early Caddo Period Burial Mound Site on the Sulphur River, Red River County, Texas
}

\author{
Timothy K. Perttula
}

\section{INTRODUCTION}

The T. N. Coles site (41RR3), also known as the Mustang Creek site (Suhm and Jelks 1962:71), is an Early Caddo period (ca. A.D. 1000-1200) site with a single burial mound constructed on a tributary to the Sulphur River in East Texas (Figure 1). The site was never investigated by a professional archaeologist, but the available information about the site and the artifact findings indicate that the burial mound contained (and may still contain) at least one burial with multiple interments, very similar to Early Caddo period shaft tombs at the Gahagan (Webb and Dodd 1939) and Mounds Plantation (Webb and McKinney 1975) sites on

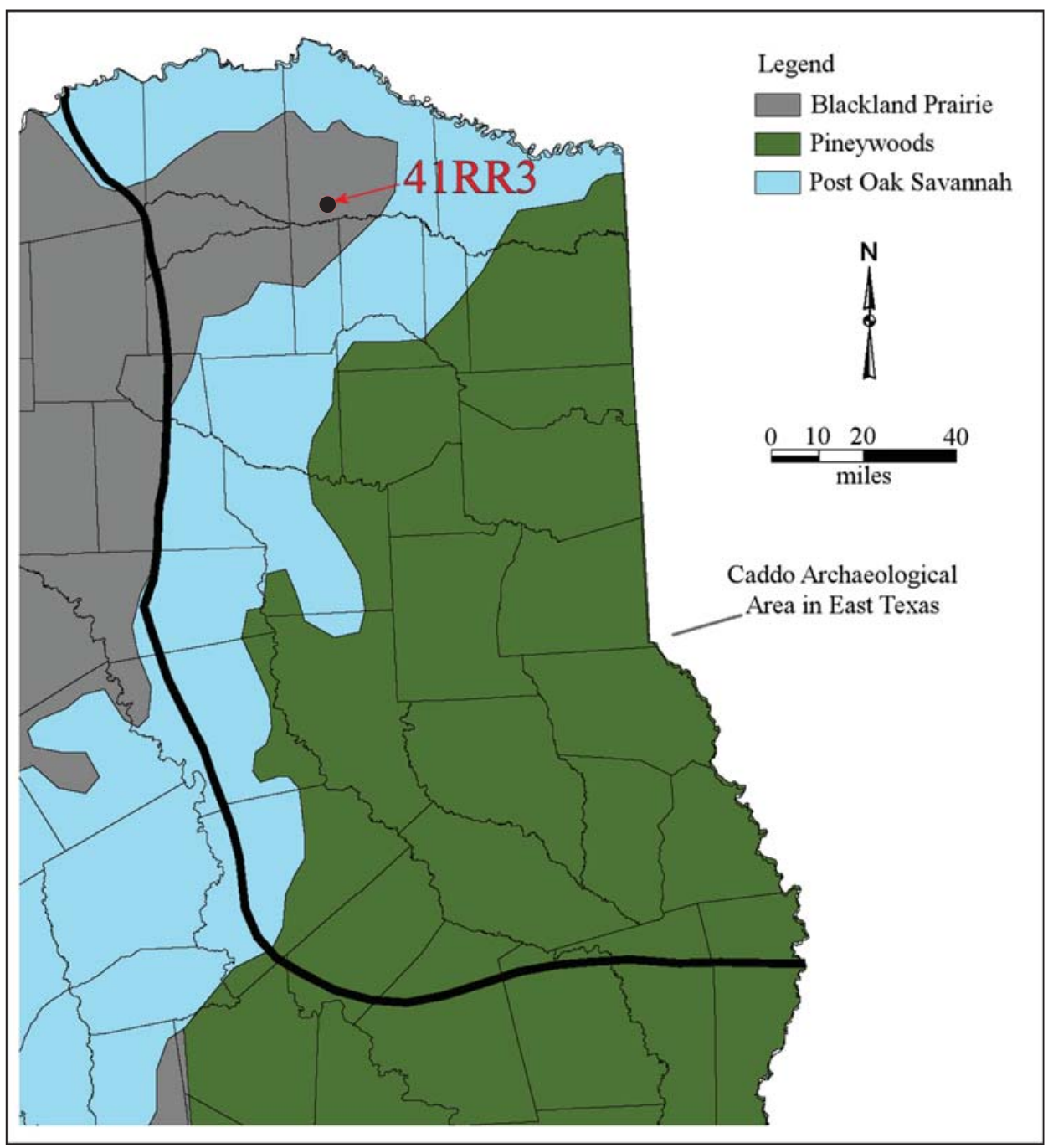

Figure 1. The location of the T. N. Coles site in East Texas. 
the Red River in Northwest Louisiana, the Crenshaw site on the Red River in Southwest Arkansas (Jackson et al. 2012; Perttula et al. 2014; Samuelsen 2014; Schambach 1982), and the George C. Davis (Story 1997 , 1998) and Boxed Springs (Perttula 2011) sites on the Neches and Sabine rivers in East Texas.

\section{SITE SETTING}

The burial mound at the T. N. Coles site is situated on the edge of an upland landform ( $330 \mathrm{ft}$. amsl) on the east side of Little Mustang Creek, a southward-flowing tributary of the Sulphur River. The current channel of the river is about $4 \mathrm{~km}$ south of the site (Figure 2).

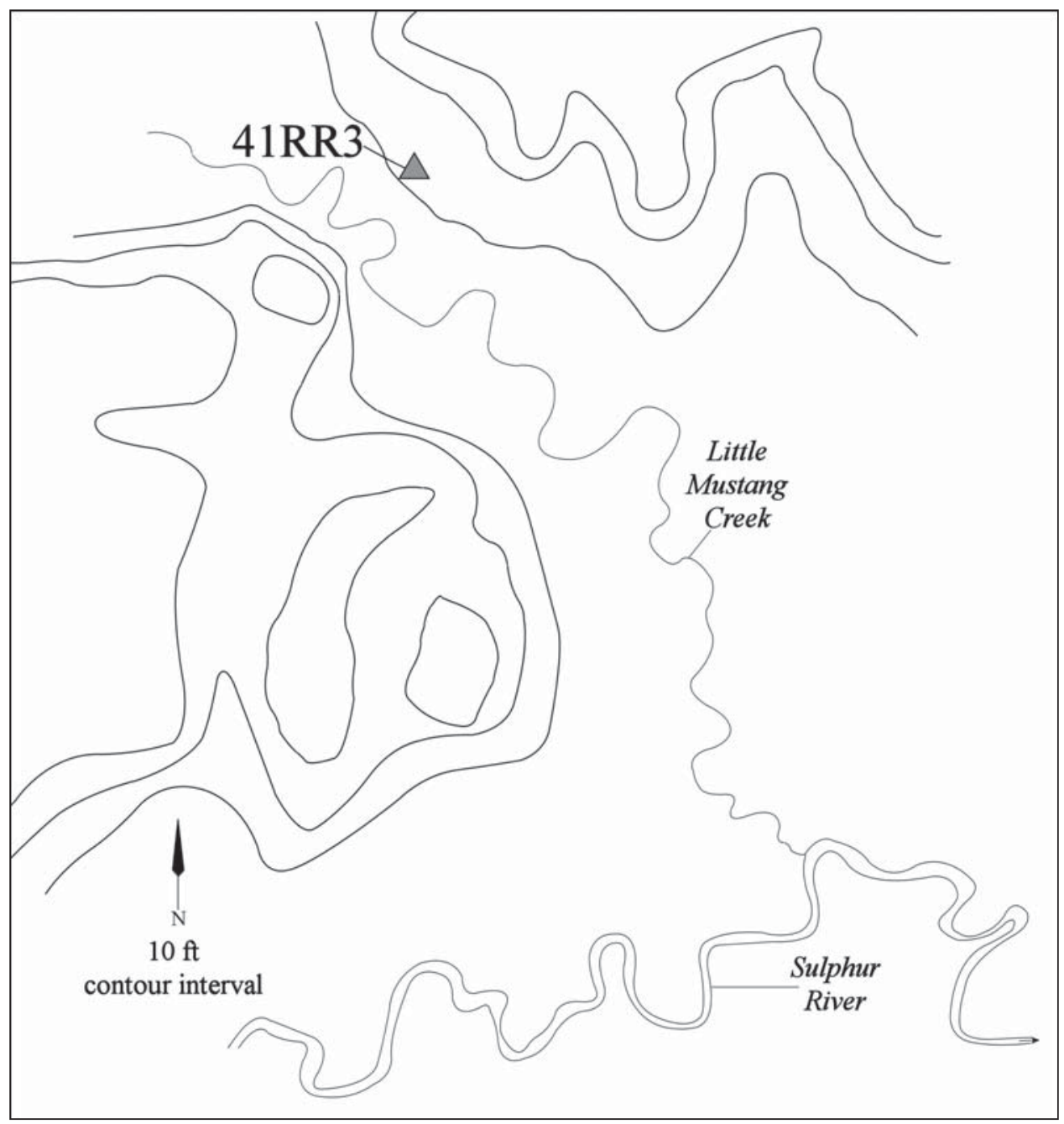

Figure 2. The location of the T. N. Coles site in the Sulphur River valley in Red River County, Texas.

According to A. T. Jackson of the University of Texas, who visited the mound site in April 1931, the mound at that time measured ca. $23 \mathrm{~m}$ in diameter and stood $3.6 \mathrm{~m}$ high (Notes from Department of Anthropology Field Notebook No. 3 for 1931, April 17, 1931). It had a 4.6 m long x $3.05 \mathrm{~m}$ wide pit in the center of the mound that had been excavated by Tom N. Coles in July 1930; he excavated the pit to ca. $3.6 \mathrm{~m}$ below the surface of the mound. At that depth, in the sandy loam mound fill, he encountered a large burial pit with multiple interred individuals, including at least two ancestral Caddo individuals with cranially 
modeled skulls (cf. Derrick and Wilson 1997). Found associated with these individuals were a number of ceramic vessels, two conch shell beads, fragments of hammered sheet copper, and a large chipped knive (i.e., a Gahagan biface, see discussion of Gahagan bifaces in Shafer [2011]). A. T. Jackson secured on loan or through donation the artifacts recovered by Coles in the burial pit, and these funerary offerings are presently in the collections at the Texas Archeological Research Laboratory at The University of Texas at Austin.

\section{CERAMIC VESSELS}

Currently remaining in the collections from the T. N. Coles site are a number of whole and fragmentary ancestral Caddo ceramic vessels. All of these vessels and vessel fragments were found together in the multiple burial feature uncovered at the base of the burial mound.

\section{Vessel 1}

Vessel 1 is a burnished carinated bottle of the Holly Fine Engraved type (see Suhm and Jelks 1962:77 and Plate 40). The bottle has a square and flat base, and stands $19.0 \mathrm{~cm}$ in height, with a neck orifice diameter of $3.7 \mathrm{~cm}$; the maximum body diameter is $14.5 \mathrm{~cm}$. The long and slightly tapered neck has four horizontal engraved lines below the lip, as well as at the top of the vessel body. The remainder of the vessel carinated body has fine engraved lines in spirals - with some lines engraved deeper than others - and parallel straight or diagonal lines running at different angles (Figure 3). The center of the spirals has a prominent excised circle, and there are excised areas on the first or second spirals opposite the excised circles. A red hematiterich clay pigment has been rubbed in the engraved lines.

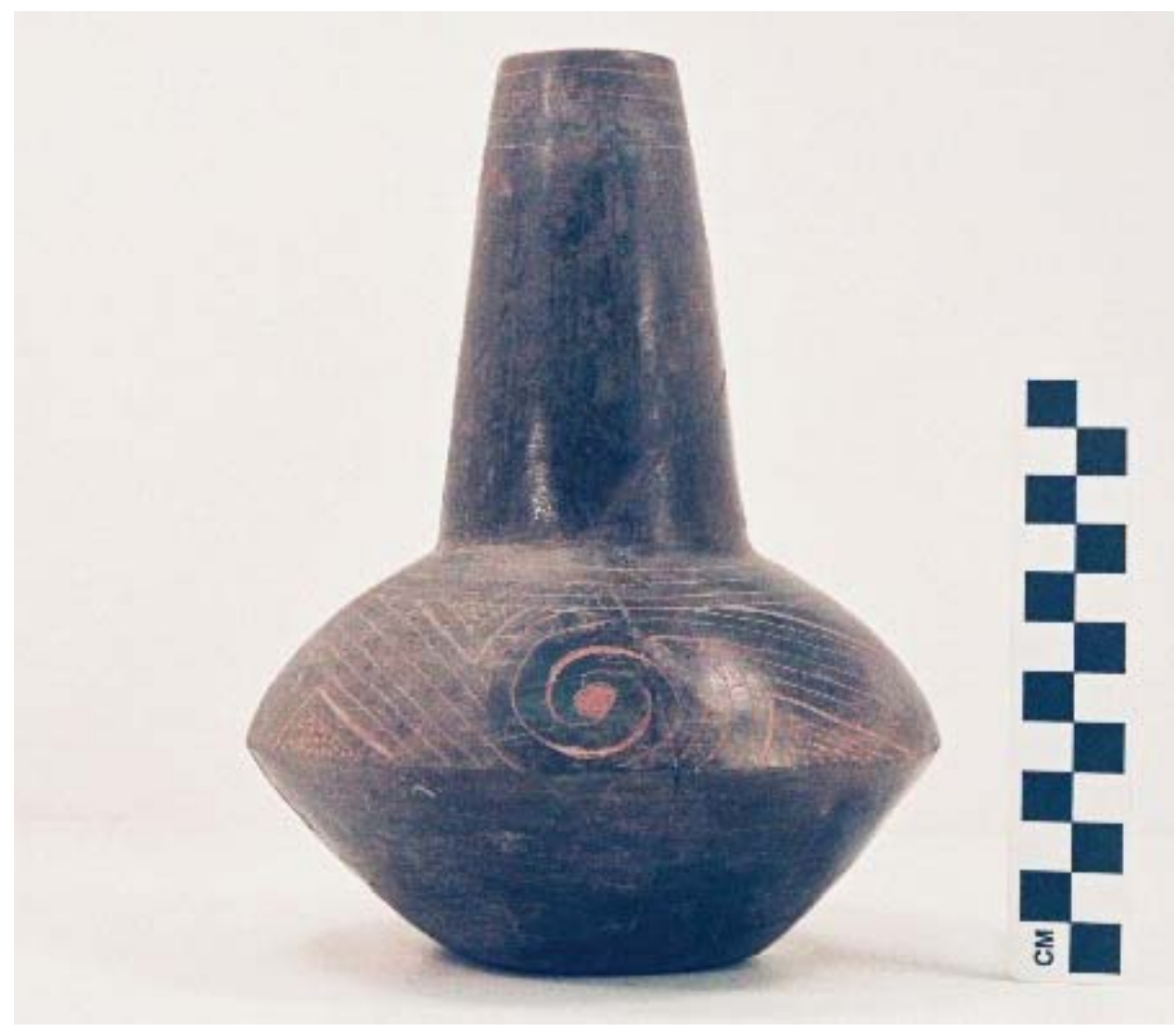

Figure 3. Holly Fine Engraved bottle (Vessel 1) from the T. N. Coles site. 


\section{Vessel 2}

This bottle stands $23.5 \mathrm{~cm}$ in height, has a $4.5 \mathrm{~cm}$ orifice diameter, and a maximum body diameter of $17.0 \mathrm{~cm}$. It is a Hickory Engraved bottle with a slightly tapered neck and a flat base (Figure 4). The bottle has four finely-drawn horizontal engraved lines at the top of the bottle neck, and six horizontal engraved lines at the top of the vessel body; the bottommost engraved line is drawn deeper than the others.

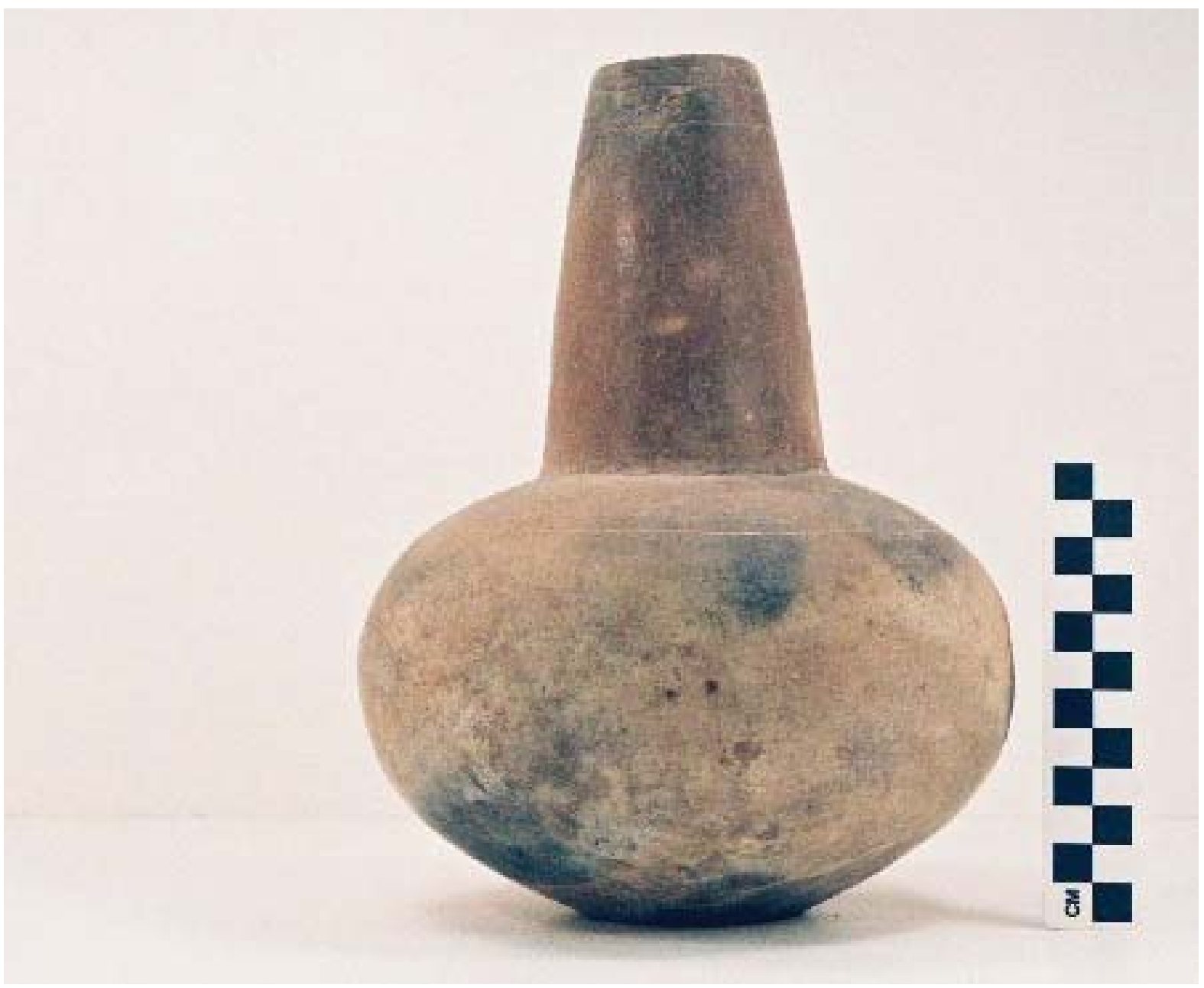

Figure 4. Hickory Engraved bottle (Vessel 2) from the T. N. Coles site.

\section{Vessel 3}

Vessel 3 is a globular Hickory Engraved bowl (Figure 5; see also Suhm and Jelks 1962:Plate 36j). The rim of the bowl has 11 closely-spaced and finely-executed horizontal engraved lines, with the middle line drawn deeper than the others. The bowl is $12.5 \mathrm{~cm}$ in height, has a $13.5 \mathrm{~cm}$ orifice diameter, and its maximum diameter on the globular body is $15.5 \mathrm{~cm}$. A similar shaped Hickory Engraved globular bowl was recovered in a non-mound cemetery at the Boxed Springs site (Perttula 2011:Figure A4.86), as was a Holly Fine Engraved type in one of the multiple Early Caddo burials at the Mounds Plantation site (Webb and McKinney 1975:Figure 9c). 


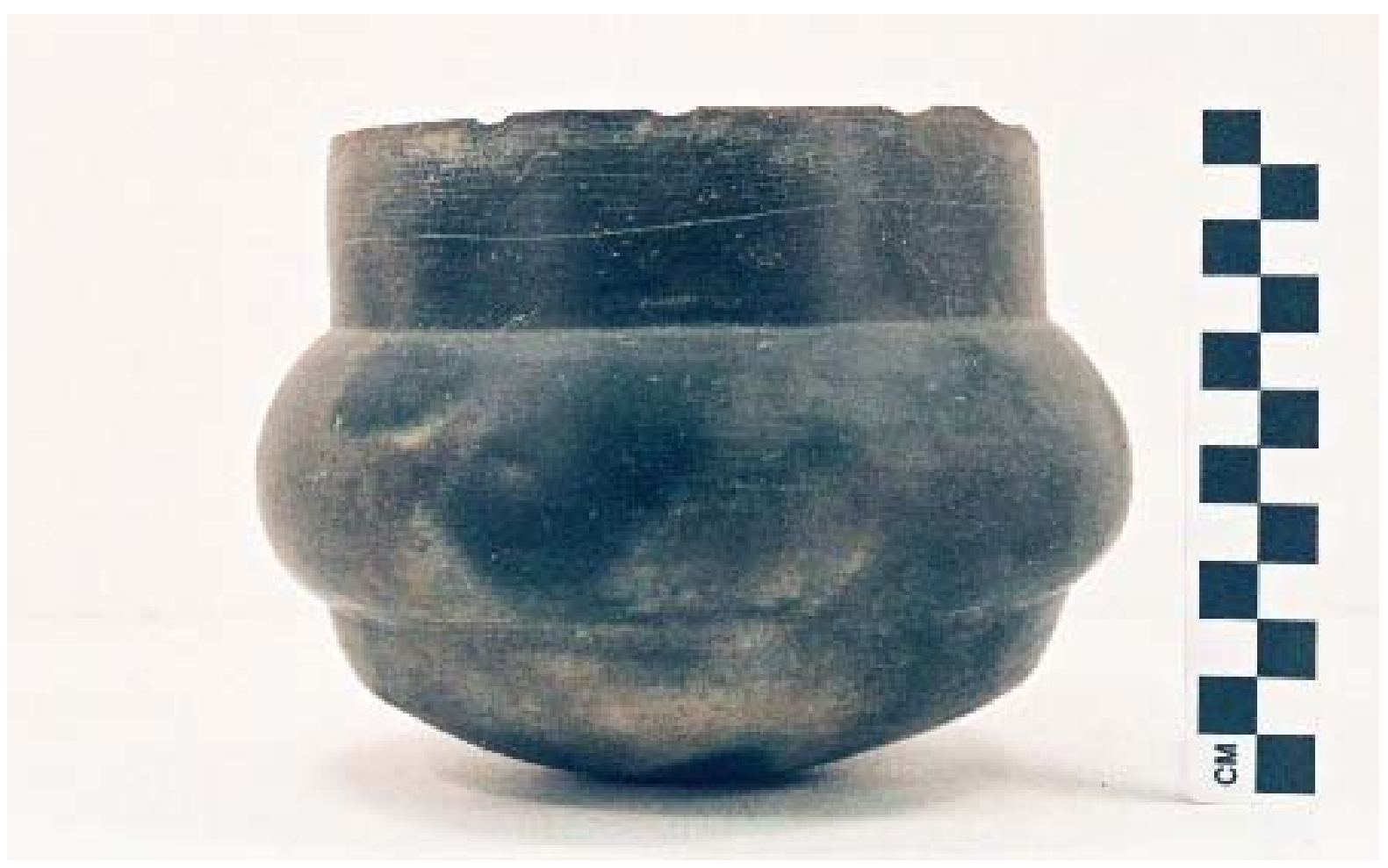

Figure 5. Hickory Engraved globular bowl (Vessel 3) from the T. N. Coles site.

\section{Vessel 4}

This is a square shouldered Holly Fine Engraved bottle with a cylindrical body and a tapered neck (Figure 6). There are finely-executed horizontal engraved lines at the top of the bottle neck as well as on the flat shoulder. The vessel body has concentric semi-circles and spirals, with excised semi-circles and triangular zones between the sets of engraved spirals. The bottle is $21.2 \mathrm{~cm}$ in height, with a $4.3 \mathrm{~cm}$ orifice diameter; the maximum body diameter is $12.7 \mathrm{~cm}$.

\section{Vessel 5}

Vessel 5 is a uniquely-shaped compound/conjoined Holly Fine Engraved bottle with two conjoined bottle bodies and a slightly tapered neck (Figure 7). The bottle stands $29.0 \mathrm{~cm}$ in height, with a $3.1 \mathrm{~cm}$ orifice diameter, and it is $19.0 \mathrm{~cm}$ in maximum body diameter.

Both vessel bodies have sets of engraved spirals divided by sets of parallel curvilinear lines. At the center of each spiral is a small excised circle (see Figure 7). The upper vessel body has five sets of vertical grooved lines that cut through the engraved decorations. These grooved lines may be a decorative element related to the Crenshaw Fluted type or at least to Hickory Engraved (see Perttula et al. 2014:Figure 83) and Spiro Engraved (see Perttula 2011:Figures A.4.106-107) vessels with vertical grooves at the Crenshaw and Boxed Springs sites. 


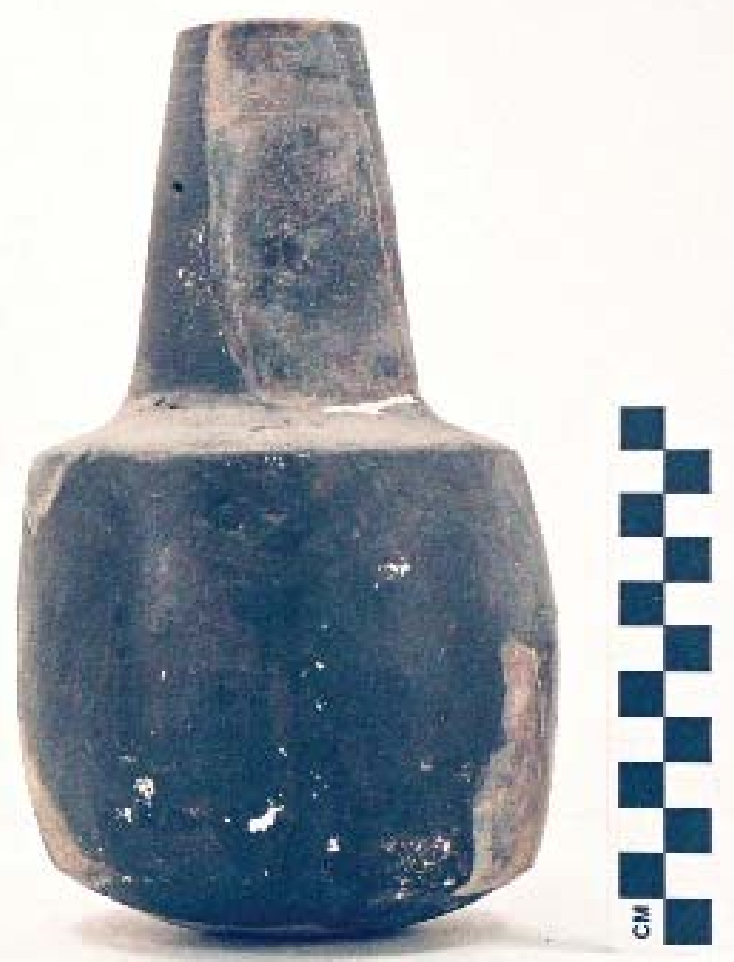

Figure 6. Holly Fine Engraved bottle (Vessel 4) from the T. N. Coles site.

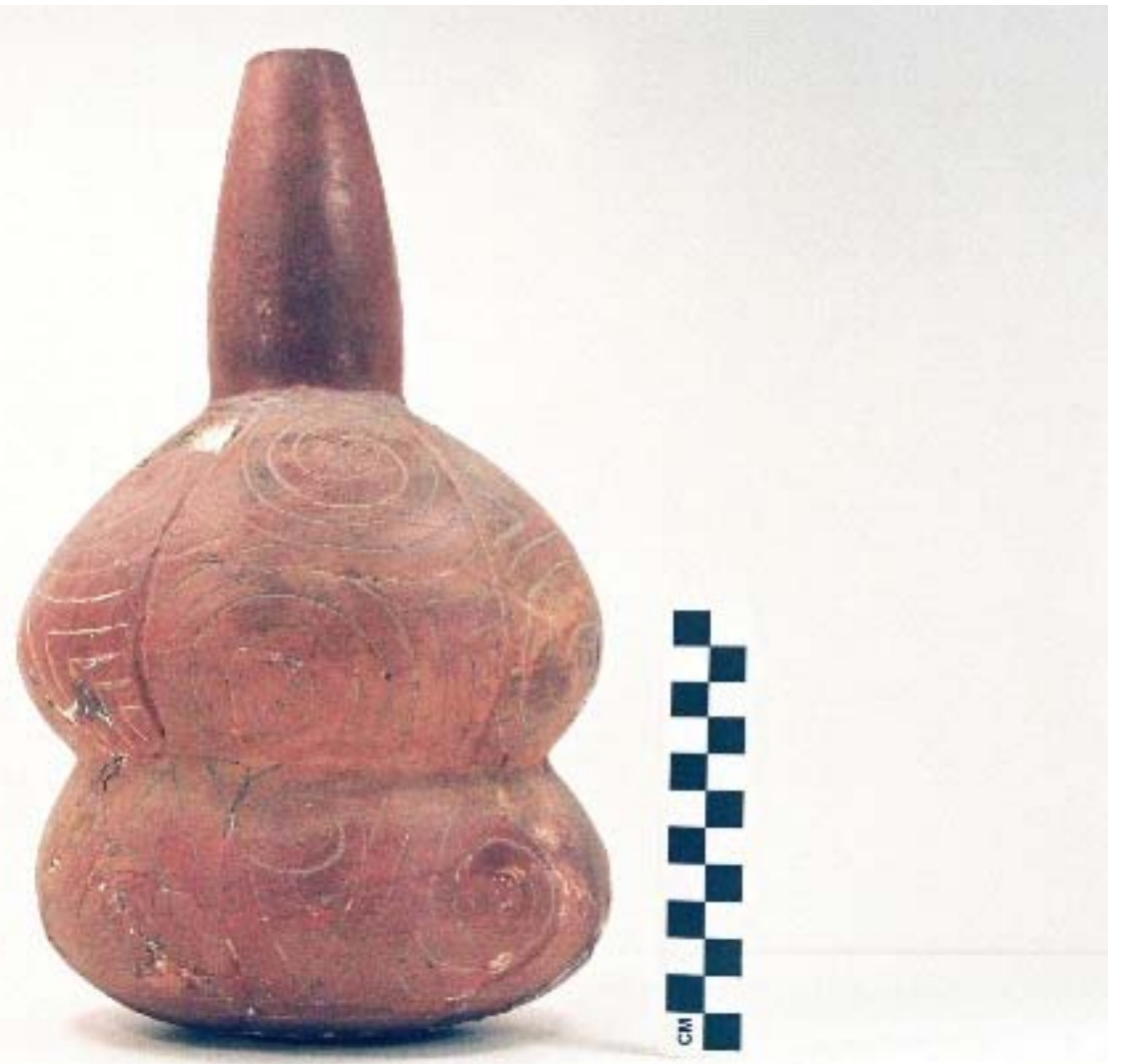

Figure 7. Holly Fine Engraved conjoined bottle (Vessel 5) from the T. N. Coles site. 


\section{Vessel 6}

This intricately decorated vessel section of a Spiro Engraved bottle is tempered with grog and came from a vessel fired in a reducing environment and cooled in the open air. The exterior vessel surface is well burnished, and a red clay pigment has been rubbed in the engraved lines. The body wall thickness is $4.3 \mathrm{~mm}$ and the base (square and flat) is $5.1 \mathrm{~mm}$ thick.

Near the base of the vessel are four opposed diagonal engraved lines, offset by concentric circles (the central circle is excised) and semi-circles and sets of parallel diagonal lines (Figure 8a). The central element on the vessel body is a diamond-shaped motif outlined by narrow zones filled with excised punctations. The diamond-shaped motif is divided in half by a diagonal bracket-shaped zone filled with excised triangles, zones filled with small excised punctations that end in excised rectangular elements, and opposed concentric semi-circles; these also have small excised zones within them (Figure 8b).

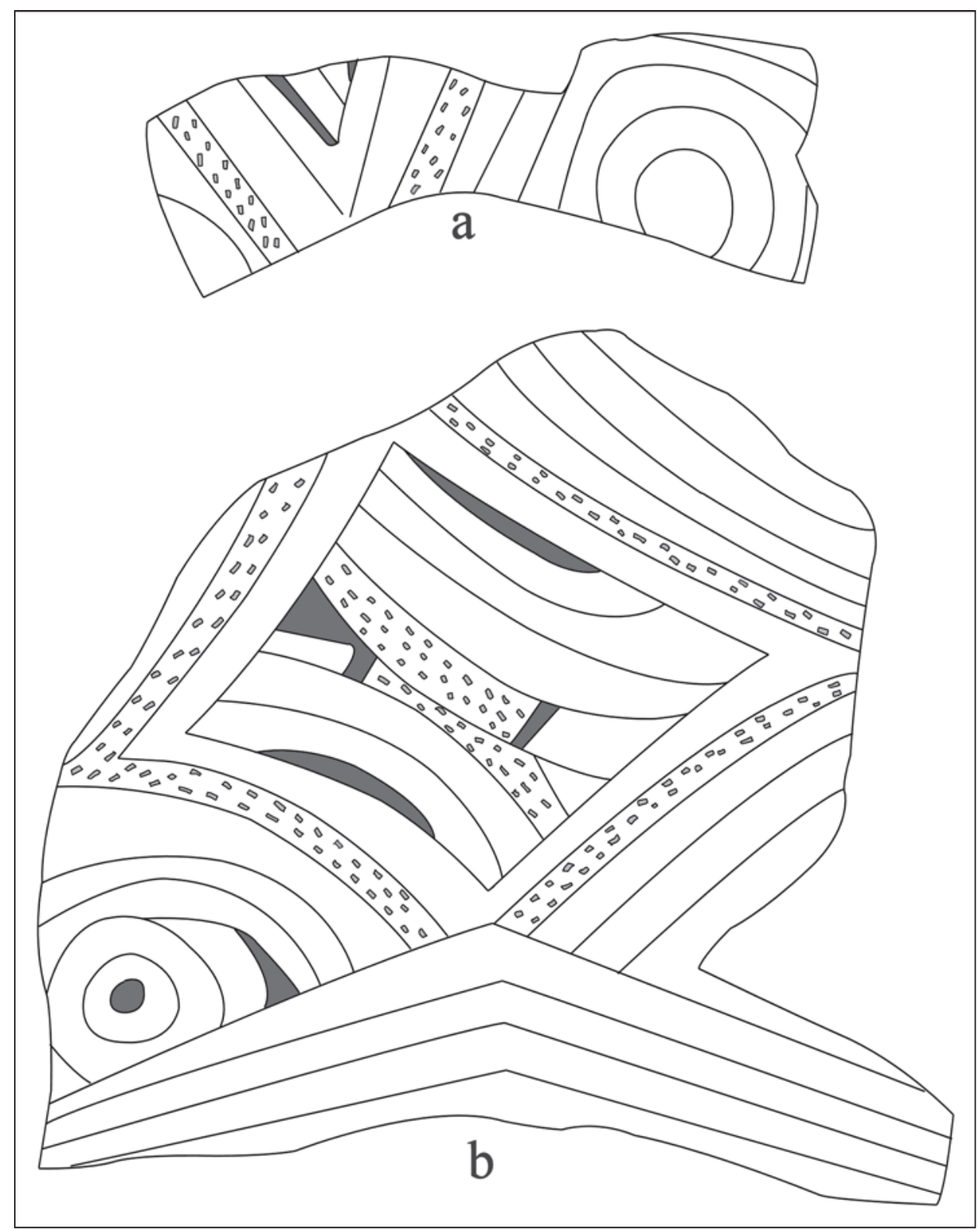

Figure 8. Decorative elements on sherds from a Spiro Engraved bottle (Vessel 6) from the T. N. Coles site. 


\section{Vessel 7}

Vessel 7 is a section of a Spiro Engraved beaker that is tempered with grog and bone. It is well burnished on the exterior vessel surface, smoothed on the interior surface, and a red pigment has been rubbed in the engraved lines (Figure 9a-b). Vessel body wall thickness is $4.5 \mathrm{~mm}$.

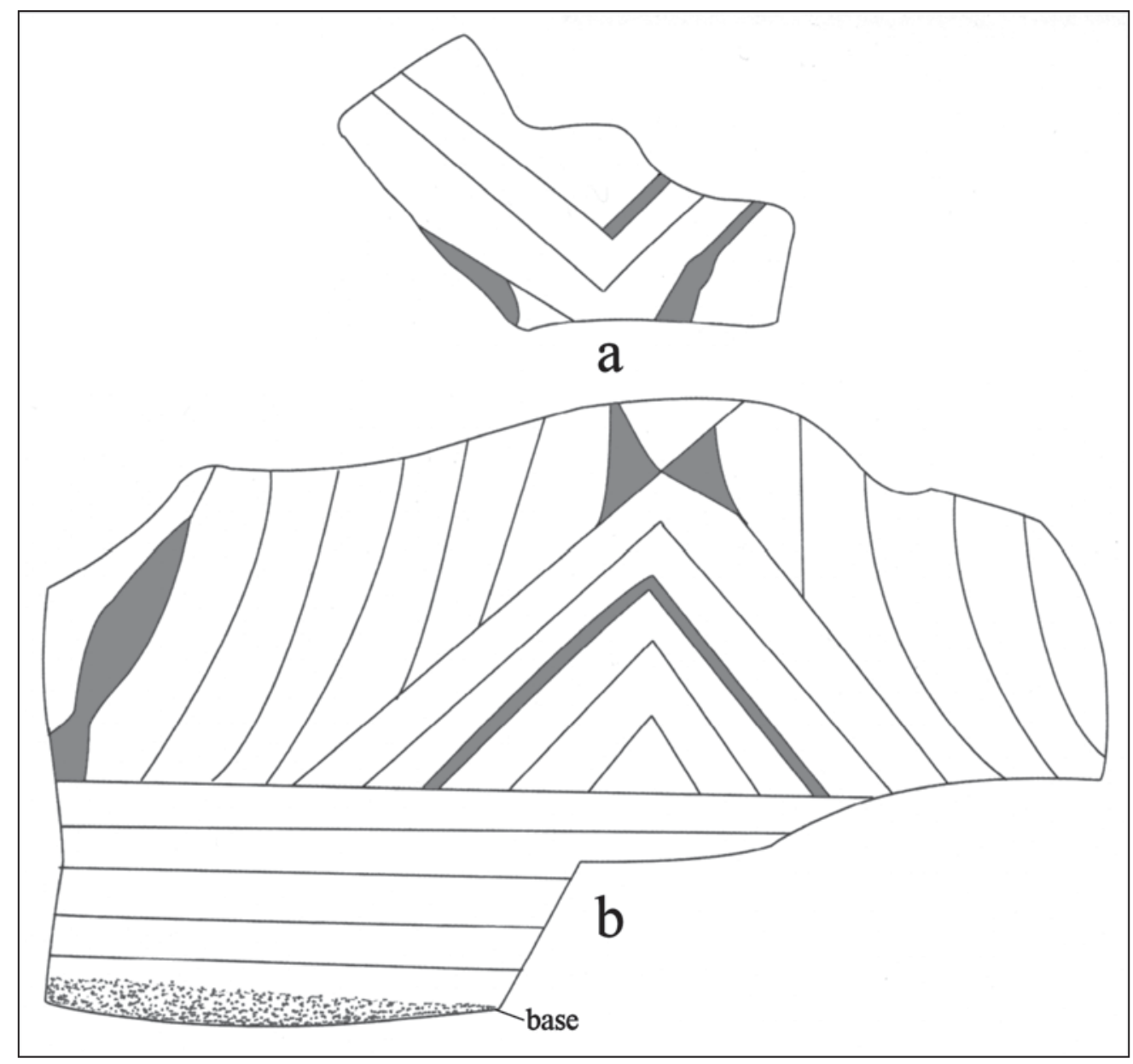

Figure 9. Decorative elements on sherds from a Spiro Engraved beaker (Vessel 7) from the T. N. Coles site.

The lowermost part of the body of the beaker has five horizontal engraved lines. Above this are sets of meshed engraved triangles; the sides of one of these triangles has bulging excised areas (see Figure 9b). At the apex of the triangles are two opposed excised triangle elements connected to sets of curvilinear engraved lines. One set of these lines is apparently divided from another set by a single bulging curvilinear excised zone on one of the curvilinear engraved lines (see Figures 9a-b).

\section{Vessel 8}

This vessel section is the partial body and base of a bone-tempered Spiro Engraved beaker (Figure 10a-b); the vessel was fired in a reducing environment and cooled in the open air. The exterior surface is burnished and the interior surface is smoothed. The body walls are $4.6 \mathrm{~mm}$ thick, and the base is $5.0 \mathrm{~mm}$ thick. 


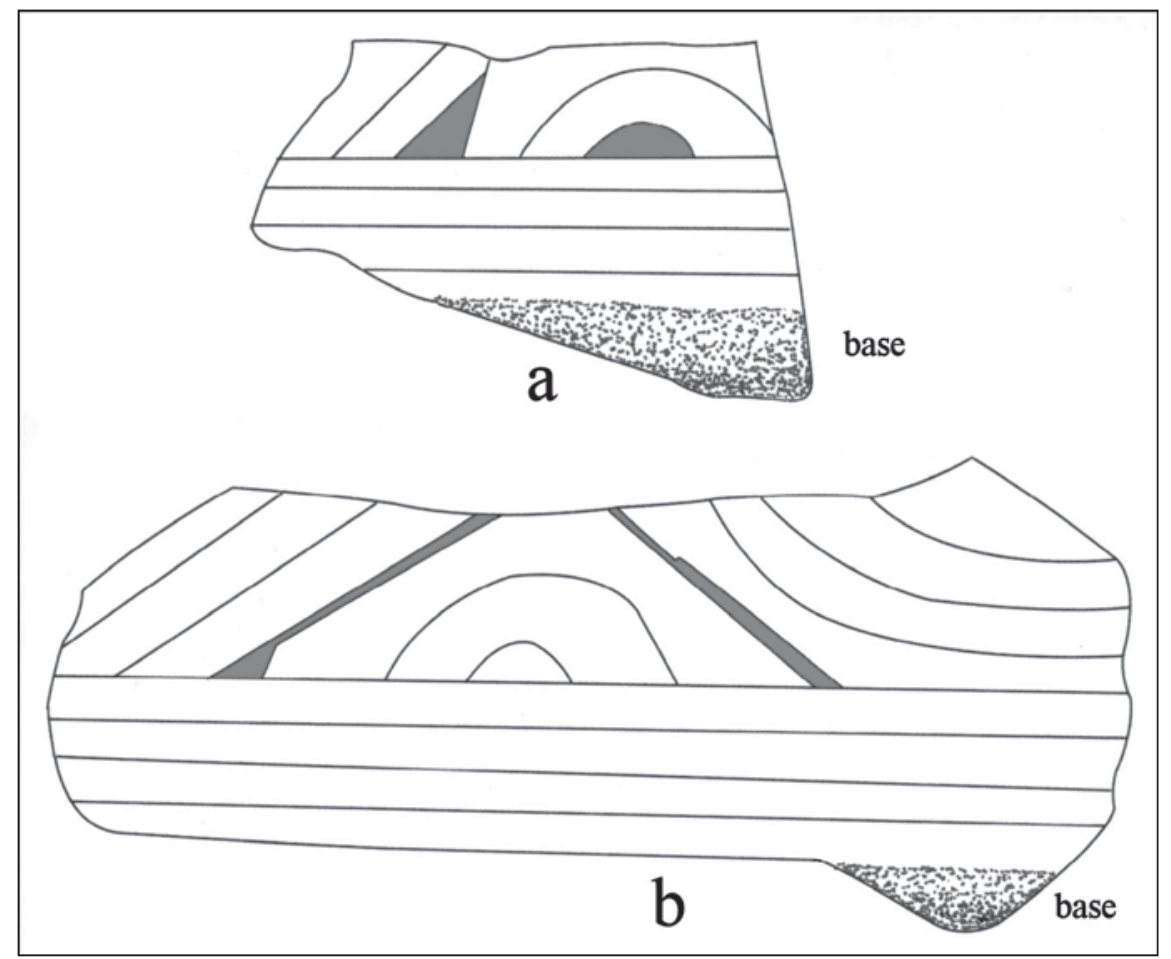

Figure 10. Decorative elements on sherds of a Spiro Engraved beaker (Vessel 8) from the T. N. Coles site.

The body of the vessel has four horizontal engraved lines above the base, and there are large triangular elements, with bulging excised sides, filled with two concentric semi-circles; the innermost concentric semicircle is excised (see Figure 10a-b). The engraved lines are filled with a red clay pigment. On either side of the triangular elements are sets of either diagonal or curvilinear engraved lines.

\section{Vessel 9}

Vessel 9 includes the lower body and base of a grog-tempered bowl or beaker, probably a Spiro Engraved vessel, that was fired and cooled in a reducing environment. Both vessel surfaces are well burnished, and vessel body walls are $3.8 \mathrm{~mm}$ thick. The lower part of the vessel body has four horizontal to diagonal engraved lines (Figure 11).

\section{Pennington Punctated-Incised carinated bowl rim sherd}

The Pennington Punctated-Incised rim sherd from the T. N. Coles site is from a burnished and grogtempered carinated bowl. The rim (7.1 $\mathrm{mm}$ in thickness) has a direct profile and a rounded lip. The core profile indicates that this sherd is from a vessel fired and cooled in a low oxygen or reducing environment. The rim decoration includes diagonal incised panels in combination with triangular-shaped incised zones filled with diagonal rows of triangular-shaped tool punctations (Figure 12). 


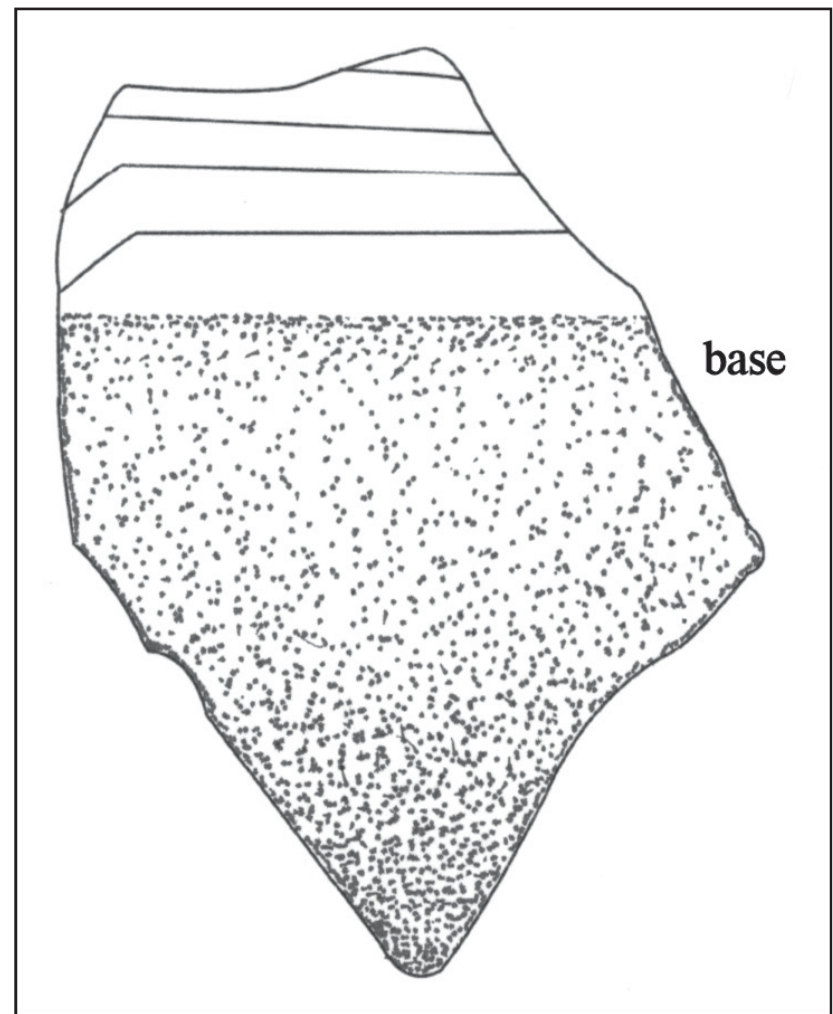

Figure 11. Decorative element on engraved bowl or beaker (Vessel 9) body/base sherd from the T. N. Coles site.

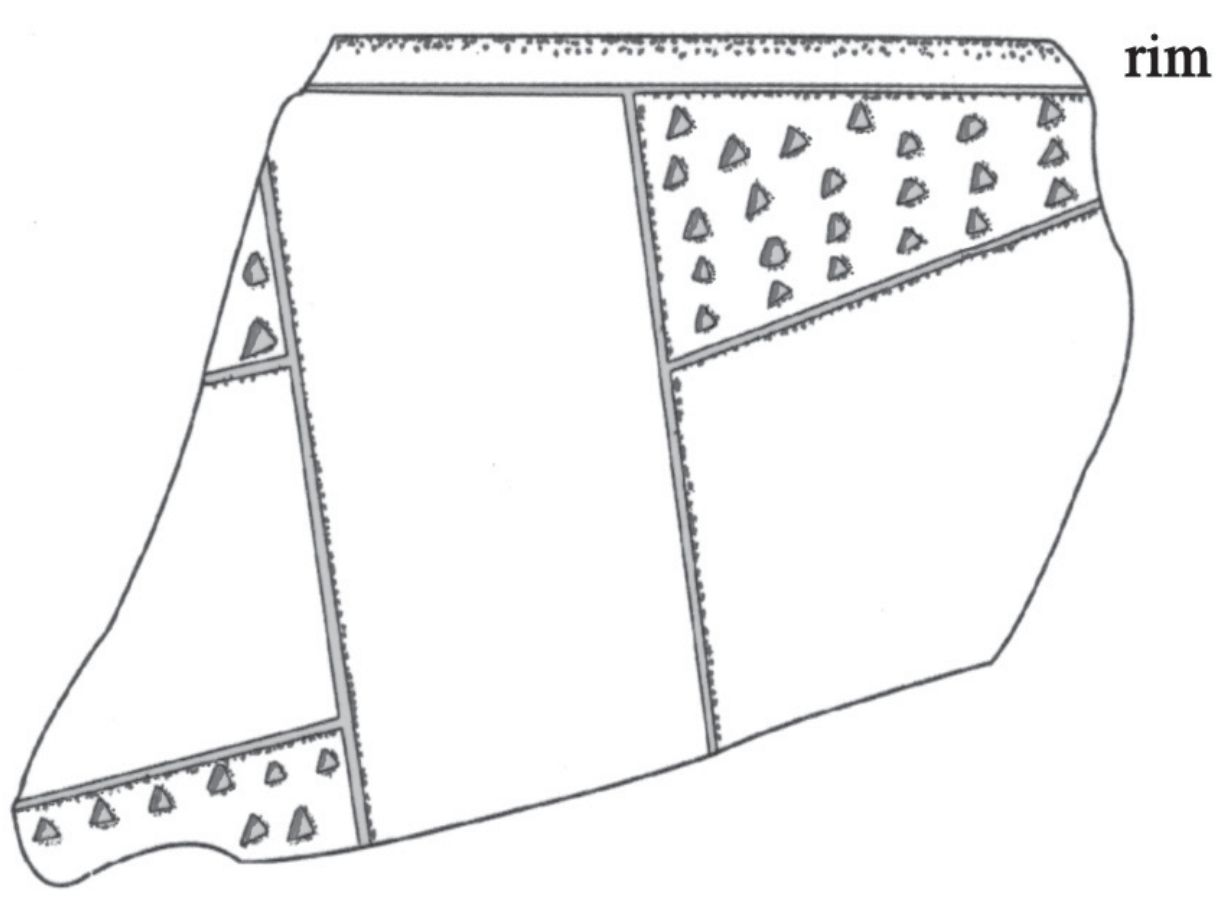

Figure 12. Decorative elements on Pennington Punctated-Incised rim sherd from the T. N. Coles site. 


\section{Miscellaneous sherds in the T. N. Coles collection}

One bottle body sherd (4.9 $\mathrm{mm}$ in thickness), tempered with grog and fired and cooled in an oxidizing environment, has sets of both horizontal and curvilinear engraved lines on the vessel body (Figure 13a); it may be from either a Holly Fine Engraved or Spiro Engraved vessel. The engraved lines have a red pigment rubbed in the engraved lines. There are also three rim sherds that may be from Hickory Engraved bottles or beakers (Figure 13b-d), or they may be part of Vessels 6 (Spiro Engraved), 7 (Spiro Engraved), and 9 (Unidentified fine ware). These rim sherds (4.3-4.5 $\mathrm{mm}$ in thickness, and with a direct rim profile and a rounded lip) are burnished on one or both sherd surfaces, suggesting they are from beakers rather than bottles with tapered necks, and they have numerous closely-spaced horizontal engraved lines; in two cases, the bottom horizontal engraved lines have been executed as a deeper cut line. They are from vessels that were fired in a reducing environment, and two of the vessels were subsequently pulled from the fire to cool in the open air.

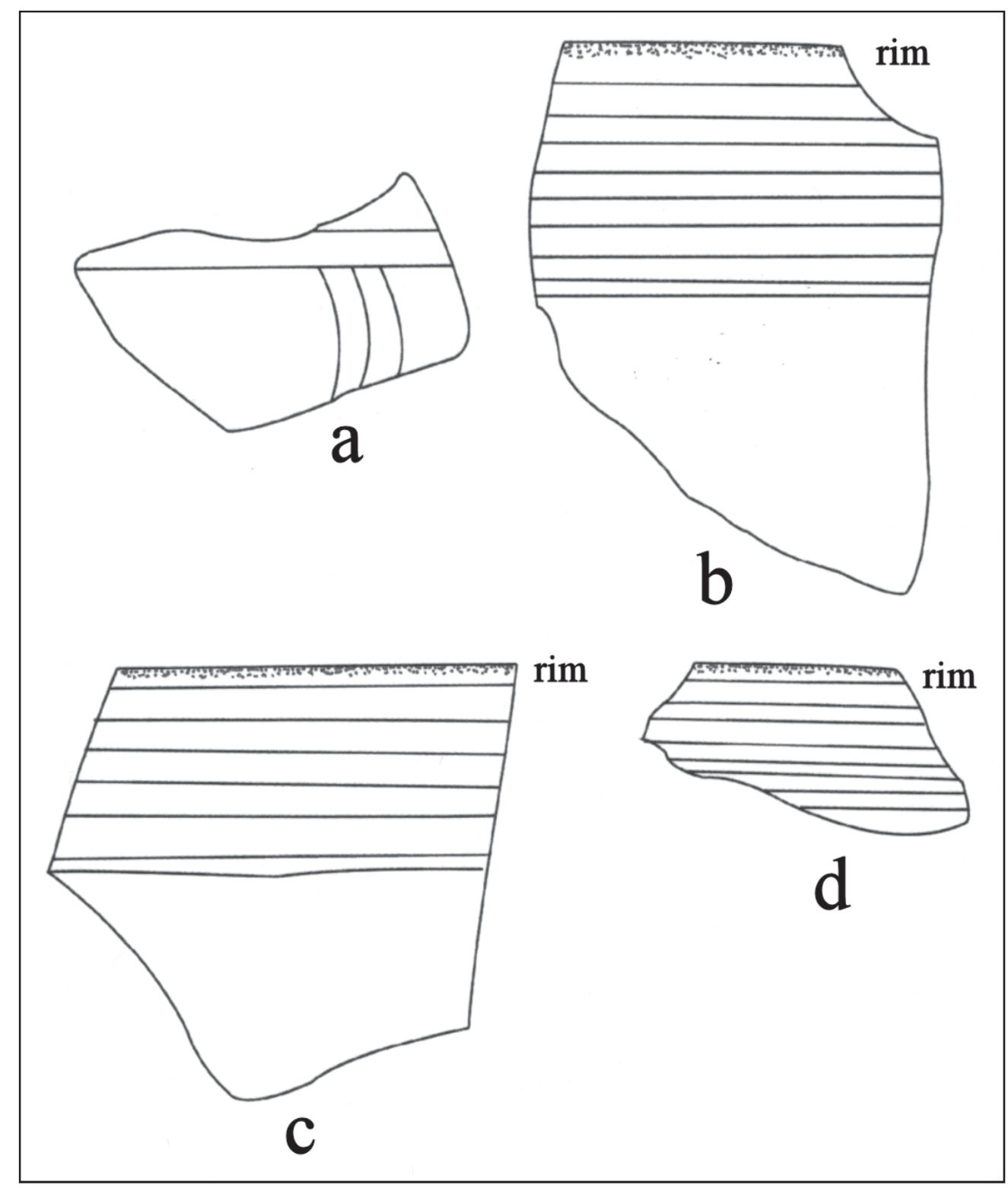

Figure 13. Decorative elements on miscellaneous engraved sherds from the T. N. Coles site: a, bottle body sherd; b-d; horizontally engraved rim sherds. 
The miscellaneous plain sherds include three grog-tempered bowl body and/or body-base sherds with an exterior smoothed surface, and a plain grog-tempered bottle body sherd. They range from 4.9-5.6 $\mathrm{mm}$ in thickness. The sherds are from vessels fired in a reducing environment and cooled in the open air.

There are also four plain bottle neck sherds from grog-tempered ( $\mathrm{n}=2$ sherds) and bone-tempered $(\mathrm{n}=2$ sherds) vessels fired and cooled in a reducing environment. they are all burnished on their exterior surfaces, and range from 3.6-4.9 $\mathrm{mm}$ in thickness. Three plain grog-tempered body sherds may be from the undecorated portions of reduced-fired beakers (see Suhm and Jelks [1962:Plate 40f] for an example of the beaker shape) as they are burnished on their exterior surfaces and smoothed on their interior surfaces. Body walls range from 3.6-4.3 $\mathrm{mm}$ in thickness.

\section{SUMMARY}

The T. N. Coles site (41RR3) is an intriguing, but poorly known Early Caddo period (ca. A.D. 10001200) mound site on the Sulphur River in East Texas. There have never been professional archaeological investigations at the site, and what is known about it comes from information obtained by A. T. Jackson at the University of Texas (UT) from the individual who dug in the burial mound in 1930, as well as the artifacts obtained by UT from the mound in 1931. Remnants of the burial mound remain to the present day, and documentation of the mound profiles ought to be undertaken by archaeologists, along with the acquisition of samples of organic remains from any features exposed in the profiles that can be radiocarbon dated. The calibrated results of those dates can be employed to establish a more refined temporal estimate as to when during the Early Caddo period the T. N. Coles site was occupied.

The 1930 excavations encountered an ancestral Caddo burial with multiple individuals at the base of the mound $(3.6 \mathrm{~m} \mathrm{bs})$, and a trove of funerary offerings, including ceramic vessels, conch shell beads, sheet copper fragments, and a Gahagan biface. The range of funerary offerings in this burial feature would seem to suggest that it was clearly associated with the death and interment of important religious or political individuals/leaders in the local Sulphur River Caddo community, as has been the case at a number of burials and tombs in Early Caddo mound centers in much of the southern Caddo area.

The ceramic vessels are all that remain of the funerary offerings acquired by UT in 1931. They include five whole vessels and varying portions of five other vessels. They include two carinated bowls, one globular bowl, one bowl or beaker, two beakers, three bottles, and one conjoined bottle. Nine of the vessels could be identified to type, namely Hickory Engraved ( $n=2)$, Holly Fine Engraved $(n=3)$, Spiro Engraved ( $n=3)$, all fine wares, and Pennington Punctated-Incised $(n=1)$. Half of the fine wares have had a red clay pigment rubbed in the engraved lines. The ceramic types recognized in the T. N. Coles vessel assemblage are formally and stylistically consistent with an ancestral Early Caddo period occupation/associated burial feature in an East Texas Caddo site. Where vessel temper information is available, three of the vessels are tempered with grog or crushed sherds, another is tempered with both grog and burned bone, and a fifth vessel has finely crushed burned bone temper.

\section{ACKNOWLEDGMENTS}

Thanks to Jonathan Jarvis for facilitating the study of the collections and records at the Texas Archeological Research Laboratory, The University of Texas at Austin. Bo Nelson took the photographs of Vessels 1-5, and Lance Trask prepared the other figures in this article. 


\section{REFERENCES CITED}

Derrick, S. M. and D. Wilson

1997 Cranial Modeling as an Ethnic Marker among the Prehistoric Caddo. Bulletin of the Texas Archeological Society 68:139-146.

Jackson, H. E., S. L. Scott, and F. F. Schambach

2012 At the House of the Priest: Faunal Remains from the Crenshaw Site (3MI6), Southwest Arkansas. In The Archaeology of the Caddo, edited by T. K. Perttula and C. P. Walker, pp. 47-85. University of Nebraska Press, Lincoln.

Perttula, T. K. (assembler)

2011 Archaeological and Archaeogeophysical Investigations at an Early Caddo Mound Center in the Sabine River Basin of East Texas. Special Publication No. 15. Friends of Northeast Texas Archaeology, Austin and Pittsburg.

Perttula, T. K., B. Nelson, M. Walters, and R. Cast

2014 Documentation of Caddo Funerary Objects from the Crenshaw Site (3MI6) in the Gilcrease Museum Collections. Special Publication No. 19. Friends of Northeast Texas Archaeology, Pittsburg and Austin.

Samuelsen, J. R.

2014 AMS and Radiocarbon Dating of the Crenshaw Site (3MI6). The Arkansas Archeologist 52:17-35.

Schambach, F. F.

1982 The Archeology of the Great Bend Region in Arkansas. In Contributions to the Archeology of the Great Bend Region, edited by F. F. Schambach and F. Rackerby, pp. 1-11. Research Series No. 22. Arkansas Archeological Survey, Fayetteville.

Shafer, H. J.

2011 Lithic Technology at the George C. Davis Site, Cherokee County, Texas. Special Publication No. 18. Friends of Northeast Texas Archaeology, Austin and Pittsburg.

Story, D. A.

1997 1968-1970 Archeological Investigations at the George C. Davis Site, Cherokee County, Texas. Bulletin of the Texas Archeological Society 68:1-113.

1998 The George C. Davis Site: Glimpses into Early Caddoan Symbolism and Ideology. In The Native History of the Caddo: Their Place in Southeastern Archeology and Ethnohistory, edited by T. K. Perttula and J. E. Bruseth, pp. 9-43. Studies in Archeology 30. Texas Archeological Research Laboratory The University of Texas at Austin.

Suhm, D. A. and E. B. Jelks (editors)

1962 Handbook of Texas Archeology: Type Descriptions. Special Publication No. 1, Texas Archeological Society, and Bulletin No. 4, Texas Memorial Museum, Austin. Reprinted in 2009, Gustav's Library, Davenport, Iowa.

Webb, C. H. and M. Dodd, Jr.

1939 Further Excavations of the Gahagan Mound: Connections with a Florida Culture. Bulletin of the Texas Archeological and Paleontological Society 11:92-126.

Webb, C. H. and R. R. McKinney

1975 Mounds Plantation (16CD12), Caddo Parish, Louisiana. Louisiana Archaeology 2:39-127. 